\title{
$\beta_{1 \mathrm{C}}$ Integrin in Epithelial Cells Correlates with a Nonproliferative Phenotype
}

\author{
Forced Expression of $\beta_{1 c}$ Inhibits Prostate Epithelial \\ Cell Proliferation
}

\author{
Mara Fornaro, ${ }^{*}$ Michela Manzotti, ${ }^{*}$ \\ Giovanni Tallini, ${ }^{*}$ Amy E. Slear, ${ }^{*}$ Silvano Bosari, ${ }^{\dagger}$ \\ Erkki Ruoslahti, ${ }^{\ddagger}$ and Lucia R. Languino* \\ From the Department of Pathology, Y Yale University School of \\ Medicine, New Haven, Connecticut; Department of Pathology, ${ }^{\dagger}$ \\ European Institute of Oncology and University of Milan School of \\ Medicine, Milan, Italy; and Cancer Research Center, ${ }^{\ddagger}$ The \\ Burnham Institute, La Jolla, California
}

The expression of the $\beta_{1 \mathrm{C}}$ integrin, an alternatively spliced variant of the $\beta_{1}$ subunit, was investigated in human adult and fetal tissues. In the adult, $\beta_{1 \mathrm{C}}$ immunoreactivity was found in nonproliferative, differentiated simple, and/or pseudostratified epithelia in prostate glands and liver bile ducts. In contrast, $\beta_{1 \mathrm{C}}$ was undetectable in stratified squamous epithelium of the epidermis and/or in hepatocytes. Luminal prostate epithelial cells expressed $\beta_{1 \mathrm{C}}$ in vivo and in vitro, but no $\beta_{1 \mathrm{C}}$ was seen in basal cells, which are proliferating cells. Fetal prostate expressed $\beta_{1 \mathrm{C}}$ in differentiated glands that had a defined lumen, but not in budding glands, indicating that $\beta_{1 \mathrm{C}}$ is a marker of prostate epithelium differentiation. The $\beta_{1 \mathrm{C}}$ and the common $\beta_{1 \mathrm{~A}}$ variants are differentially distributed: $\beta_{1 \mathrm{~A}}$ was found in luminal and basal epithelial as well as in stromal cells in the prostate. In the liver, $\beta_{1 \mathrm{C}}$ and $\beta_{1 \mathrm{~A}}$ were coexpressed in biliary epithelium, whereas vascular cells expressed only $\beta_{1 \mathrm{~A}}$. Because we found $\beta_{1 \mathrm{C}}$ in nonproliferative and differentiated epithelium, we investigated whether $\beta_{1 \mathrm{c}}$ could have a causal role in inhibiting epithelial cell proliferation. The results showed that exogenous expression of a $\beta_{1 \mathrm{C}}$, but not of a $\beta_{1 \mathrm{~A}}$, cytoplasmic domain chimeric construct, completely inhibited thymidine incorporation in response to serum by prostate cancer epithelial cells. Consistent with these in vitro results, $\beta_{1 C}$ appeared to be downregulated in prostate glands that exhibit regenerative features in benign hyperplastic epithelium. These data show that the presence of $\beta_{1 C}$ integrins in epithelial cells correlates with a nonproliferative, differentiated phenotype and is growth inhibitory to prostate epithelial cells in vitro. These findings indicate a novel pathophysiological role for this integrin variant in epithelial cell proliferation. (Am J Patbol 1998, 153:1079-1087)

Cell interactions with extracellular matrix proteins control proliferation, differentiation, and survival, ${ }^{1-3}$ as well as tumor growth, angiogenesis, and metastasis. ${ }^{4}$ These interactions are predominantly mediated by integrins, cell adhesion receptors composed of an $\alpha$ and a $\beta$ subunit. $^{5-7}$ In addition to mediating physical interactions, integrins signal intracellularly through their cytoplasmic domains. ${ }^{8}$ The cytoplasmic domains also control integrin affinity for ligands and subcellular localization. ${ }^{8-10}$

The cytoplasmic domain of the $\beta_{1}$ subunit, in its canonical form $\left(\beta_{1 \mathrm{~A}}\right)$, is highly conserved from fungi and invertebrates to vertebrates. ${ }^{11}$ Experimental modifications of the $\beta_{1}$ cytoplasmic domain have been shown to affect cell proliferation, ${ }^{12,13}$ development, ${ }^{14}$ migration, ${ }^{15,16}$ integrin localization, ${ }^{17,18}$ and mitogen-activated protein kinase activation ${ }^{19,20}$ and phosphorylation of focal adhesion kinase or paxillin. ${ }^{15,21-23}$ Alternative splicing events, by creating variant cytodomains, generate functionally distinct integrin complexes. ${ }^{8}$ Alternatively spliced forms of the $\beta\left(\beta_{1}, \beta_{3}, \beta_{4}\right.$, and $\left.\beta_{5}\right)$ and $\alpha\left(\alpha_{3}, \alpha_{6}\right.$, and $\alpha_{7}$ ) integrin cytoplasmic domains have been identified, 8,24 thus adding further complexity to the regulatory pathways mediated by integrins.

The integrin $\beta_{1}$ variants are known as: the canonical $\beta_{1 \mathrm{~A}}, \beta_{1 \mathrm{~B}}, \beta_{1 \mathrm{C}}, \beta_{1 \mathrm{C}-2}$, and $\beta_{1 \mathrm{D}}$; they differ in the $\mathrm{COOH}-$ terminal sequences. ${ }^{8}$ The $\beta_{1 \mathrm{C}}$ integrin (formerly $\beta_{1 \mathrm{~S}}$ ) ${ }^{25}$ is

Supported in part by National Institutes of Health Grants CA 71870 and DK 52670, Donaghue Medical Research Foundation grant 95-006, a Milheim Foundation Award (to LRL), a Donaghue Medical Research Foundation Fellowship Award (to MF), and a fellowship from the AmericanItalian Cancer Foundation (to MM).

MF and MM contributed equally to this report.

MM's present address: Department of Pathology, European Institute of Oncology, Milan, Italy.

Accepted for publication July 10, 1998.

Address reprint requests to Dr. Lucia R. Languino, Department of Pathology, Yale University School of Medicine, P.O. Box 208023, 310 Cedar Street, New Haven, CT 06520. E-mail: lucia.languino@yale.edu. 
Figure 1. The $\beta_{1 \mathrm{C}}$ integrin is expressed in luminal epithelium of adult prostate but not in the epidermis. The immunohistochemical analysis was performed on adult prostate (A through D) and on adult skin tissue sections ( $E$ and $F$ ) using $1.85 \mu \mathrm{g} / \mathrm{ml}$ affinitypurified antibody to $\beta_{1 \mathrm{C}}$ (A and $\mathrm{E}$ ); $1.85 \mu \mathrm{g} / \mathrm{ml}$ of nonimmune rabbit IgG (B and $F) ; 5 \mu \mathrm{g} / \mathrm{ml}$ AE1/AE3, monoclonal antibody to type I and type II cytoker-

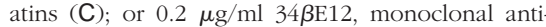
body to cytokeratins $1,5,10$, and 14 (D). Magnification, $\times 200$. Note that $\beta_{1 \mathrm{C}}$ is undetectable in the basal layer of the adult prostate gland (A).
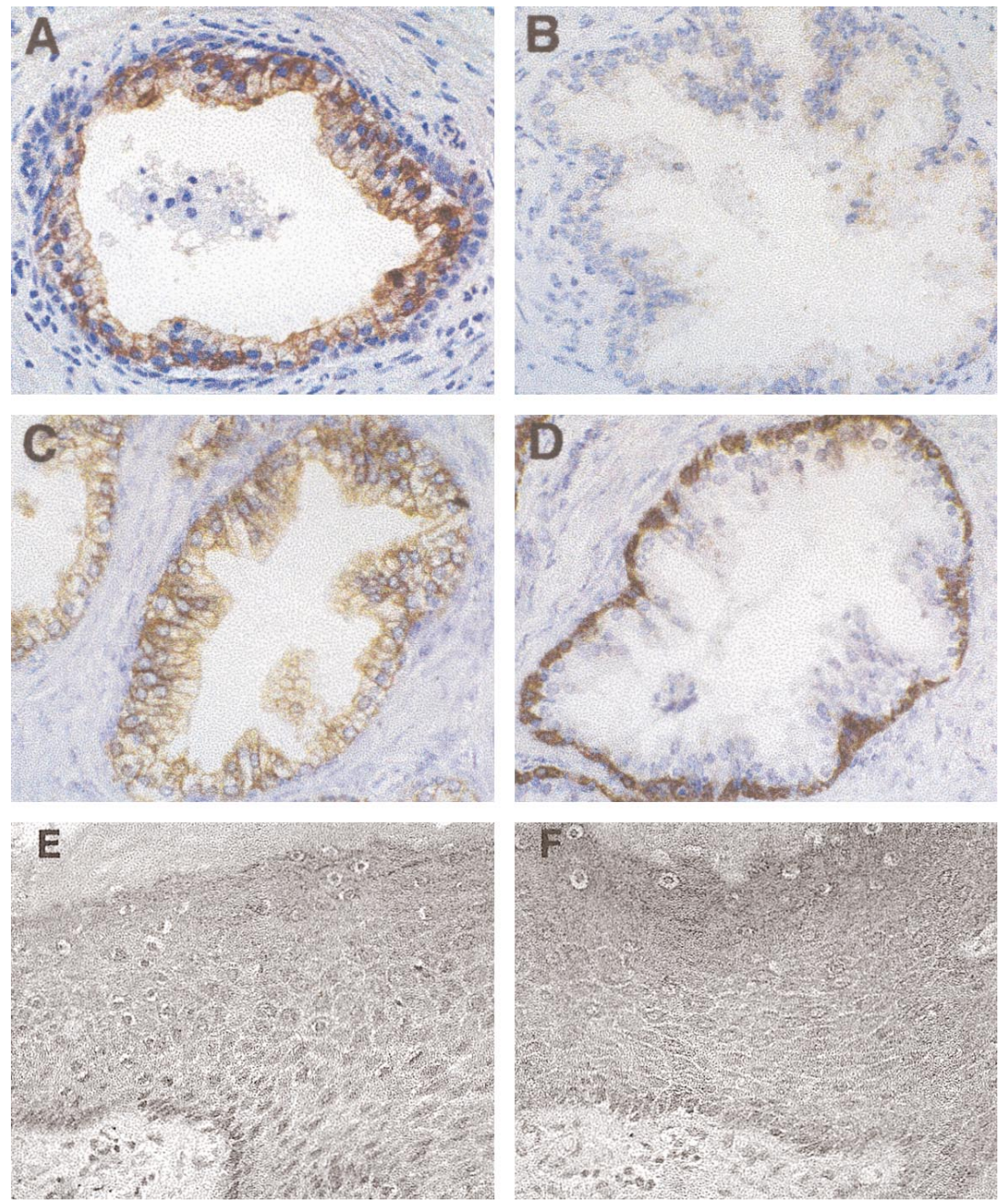

generated by the presence of an unspliced intervening 116-bp sequence (exon C), which causes a frame shift in the $3^{\prime}$ end of the $\beta_{1}$ subunit and codes for a unique 48 -amino acid $\mathrm{COOH}$-terminal sequence. Unlike $\beta_{1 \mathrm{~A}}, \beta_{1 \mathrm{C}}$ inhibits cell proliferation and is downregulated in cancer cells. ${ }^{12,13,26}$

We show here that $\beta_{1 \mathrm{C}}$ is expressed in a subset of epithelial cells exhibiting a nonproliferating and differentiated phenotype, and that it is lost in regenerative areas of prostate glands. We also provide evidence suggestive of a causal role for the $\beta_{1 \mathrm{C}}$ cytodomain in suppressing epithelial cell proliferation.

\section{Materials and Methods}

\section{Cells and Reagents}

The PC3 human prostatic carcinoma cell line was obtained from American Type Culture Collection (Manassas, VA). PC3 cells were maintained in RPMI (Life Technologies Inc., Gaithersburg, MD) supplemented with 10\% heat-inactivated fetal calf serum (FCS) (Gemini Bioproducts Inc., Calabasas, CA), 2 mmol/L glutamine (Gemini Bioproducts Inc.), $100 \mu \mathrm{g} / \mathrm{ml}$ streptomycin-100 U/ml pen- icillin (Gemini Bioproducts Inc.), $0.1 \mathrm{mmol} / \mathrm{L}$ nonessential amino acids (Life Technologies), and $1 \mathrm{mmol} / \mathrm{L}$ sodium pyruvate (Life Technologies). Human prostate luminal epithelial cells, $\mathrm{BPH}-1,{ }^{27}$ were maintained in RPMI supplemented with $2.5 \% \mathrm{FCS}, 2 \mathrm{mmol} / \mathrm{L}$ glutamine, and 100 $\mu \mathrm{g} / \mathrm{ml}$ streptomycin-100 U/ml penicillin.

Rabbit antibodies specific for the $\beta_{1 \mathrm{C}}$ or the $\beta_{1 \mathrm{~A}}$ subunit cytoplasmic domains were generated and affinity purified as previously described. ${ }^{26}$ The following antibodies were used: fluorescein isothiocyanate-conjugated rat monoclonal antibody to mouse CD4, clone YTS 191.1 (Caltag Laboratories, San Francisco, CA); mouse monoclonal antibody to the human $\beta_{1}$ integrin extracellular domain, mAb 13 (Beckton Dickinson, San Jose, CA) and kindly provided by Dr. K. M. Yamada (National Institutes of Health, Bethesda, MD); mouse monoclonal antibodies to basal cytokeratins $1,5,10$, and 14 , clone $34 \beta E 12$ (Enzo Diagnostic, Farmingdale, NY) or to type I and type II cytokeratins, clone AE1/AE3 (Boehringer Mannheim, Indianapolis, IN); and mouse monoclonal antibody to cytokeratins 8 and 18, clone CAM 5.2 (Becton Dickinson). Fluorescein isothiocyanate-rat immunoglobulin $G$ (IgG) were purchased from Caltag. 

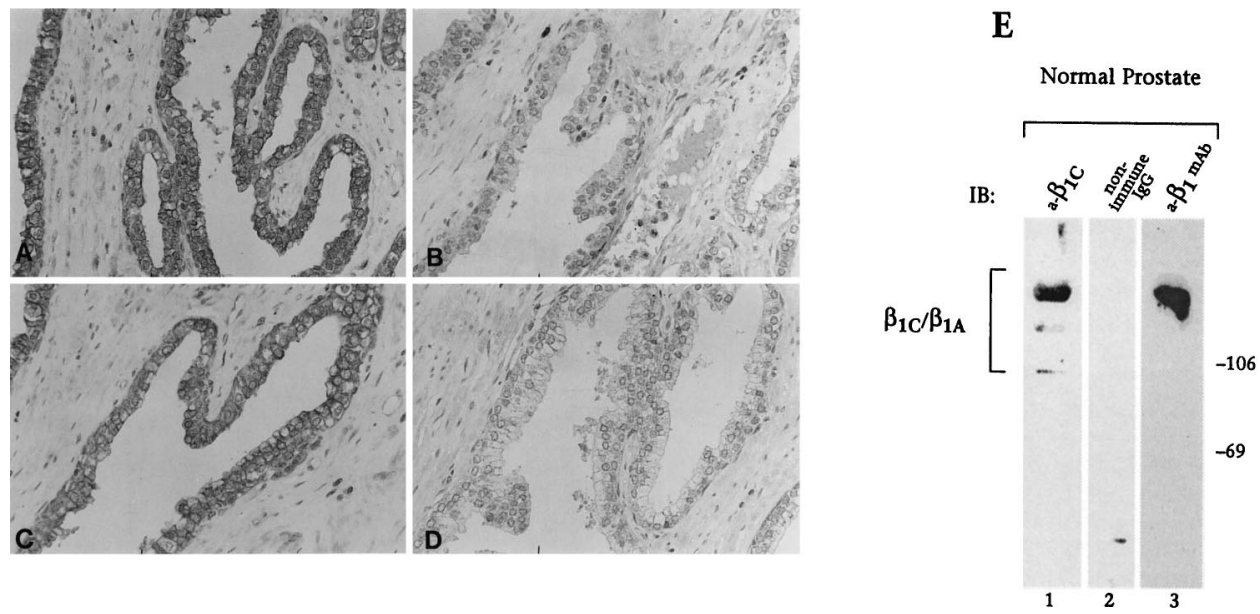

$\mathbf{F}$

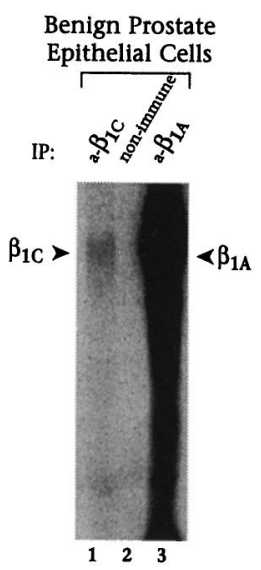

Figure 2. In vivo and in vitro expression of $\beta_{1 \mathrm{C}}$ in prostate cells. A through $\mathrm{D}$, a representative case of adult normal prostate tissue is shown. $\beta_{1 \mathrm{C}}$ immunostaining (A) was specifically inhibited by antibody absorption on the $\beta_{1 \mathrm{C}} 785$ to 808 peptide $(10 \mu \mathrm{g} / \mathrm{ml})$ used as antigen (B) but not on an irrelevant peptide (C). The affinity-purified antibody to $\beta_{1 \mathrm{C}}$ (A through C) or nonimmune rabbit IgG (D) were used at a final concentration of $5 \mu \mathrm{g} / \mathrm{ml}$. E: newborn (1-month-old) prostate tissue detergent extract was electrophoresed on $7.5 \%$ SDS-polyacrylamide gel under reducing conditions, transferred to nitrocellulose membranes, and immunostained using $5 \mu \mathrm{g} / \mathrm{ml}$ affinity-purified antibody to $\beta_{1 \mathrm{C}}$ (a- $\beta_{1 \mathrm{C}}$, lane 1); $5 \mu \mathrm{g} / \mathrm{ml}$ nonimmune rabbit IgG (nonimmune IgG, lane 2 ); or $2.5 \mu \mathrm{g} / \mathrm{ml} \mathrm{mAb} 13$, monoclonal antibody to $\beta_{1}$ (a- $\beta_{1}$ mAb, lane 3 ). Proteins were visualized by enhanced chemiluminescence. Prestained marker proteins in kd are shown. The bracket (E) indicates the expected electrophoretic mobility of $\beta_{1 \mathrm{C}}$ and $\beta_{1 \mathrm{~A}}$. F: BPH-1 cells were surface iodinated and proteins immunoprecipitated using rabbit antisera either to $\beta_{1 \mathrm{C}}\left(\mathrm{a}-\beta_{1 \mathrm{C}}\right.$, lane 1) or $\beta_{1 \mathrm{~A}}$ (a- $\beta_{1 \mathrm{~A}}$, lane 3 ), or normal rabbit serum (non immune, lane 2$)$. The immunocomplexes were separated on a $7.5 \%$ SDS-polyacrylamide gel under reducing conditions and visualized by autoradiography. Arrowheads indicate $\beta_{1 \mathrm{C}}$ and $\beta_{1 \mathrm{~A}}$. Magnification, $\times 200$ (A through D).

\section{Tissue Specimens}

Samples (autopsy or surgical specimens) were obtained from the files of the Department of Pathology at Yale New Haven Hospital. The following adult tissues were included in the study: benign prostate (62 samples, including 25 benign prostatic hyperplastic samples), normal liver (12 samples), normal gallbladder (4 samples), normal kidney (5 samples), and normal lung (1 sample). Developing tissues from spontaneous or therapeutic abortions corresponding to different gestational ages were also included: prostate (4 samples, 18 to 22 weeks; 9 samples, 23 weeks or later) and liver (3 samples, 16 to 19 weeks). Hematoxylin and eosin sections were analyzed from all samples to assess the integrity of the tissue selected for the evaluation of $\beta_{1 \mathrm{C}}, \beta_{1 \mathrm{~A}}$, or cytokeratin immunoreactivity. All tissues were obtained under review board-approved protocols.

\section{Immunohistochemistry}

Immunostaining of $\beta_{1 \mathrm{C}}, \beta_{1 \mathrm{~A}}$, and cytokeratins was performed essentially as described, ${ }^{26}$ with minor modifications. For immunostaining of liver specimens, nonspecific binding of biotin/avidin was prevented using the Avidin/ Biotin blocking kit from Vector Laboratories (Burlingame, $\mathrm{CA}$ ), according to the manufacturer's instructions. For immunostaining of prostate specimens, endogenous peroxidase was quenched with $3 \% \mathrm{H}_{2} \mathrm{O}_{2}$ for 5 minutes at room temperature, microwave treatment was avoided, blocking was achieved with either $50 \%$ goat or horse serum in Tris-buffered saline containing $0.2 \%$ bovine serum albumin for 20 minutes at room temperature; each incubation step was followed by three washes with Trisbuffered saline. The specificity of the affinity-purified an- tibody to the $\beta_{1 \mathrm{c}} 785$ to 808 peptide ${ }^{12}$ in immunohistochemical staining was confirmed as follows: before the immunostaining procedure, the affinity-purified antibody to $\beta_{1 \mathrm{C}}$ was preincubated for 30 minutes at $4^{\circ} \mathrm{C}$ with 10 to $30 \mu \mathrm{g} / \mathrm{ml}$ of either $\beta_{1 \mathrm{c}} 785$ to 808 peptide or a control fibrinogen-derived peptide. ${ }^{28}$

\section{Immunoblotting and Immunoprecipitation}

Frozen prostate tissue, obtained from autopsy specimens, was homogenized using lysis buffer containing $100 \mathrm{mmol} / \mathrm{L}$ Tris, $\mathrm{pH} 7.5,150 \mathrm{mmol} / \mathrm{L} \mathrm{NaCl}, 0.1 \%$ Triton X-100 (Sigma Chemical Co., St. Louis, MO), 5\% sodium dodecyl sulfate (SDS; American Bioanalytical, Natick, MA), $1 \mathrm{mmol} / \mathrm{L}$ phenylmethylsulfonyl fluoride (Life Technologies), $10 \mu \mathrm{g} / \mathrm{ml}$ leupeptin (Calbiochem, San Diego, CA), 1 mmol/L benzamidine (Sigma), 1 mol/L D-phenylalanyl-L-prolyl-L-arginine chloromethyl ketone (Boehringer Mannheim), $10 \mu \mathrm{g} / \mathrm{ml}$ soybean trypsin inhibitor (Life Technologies), using an OMNI 2000 homogenizer (OMNI International Inc., Gainesville, VA). Insoluble material was removed by centrifugation at 14,000 $\times g$ for 30 minutes at $4^{\circ} \mathrm{C}$. The protein content in each lysate was quantitated using the BCA protein assay reagent (Pierce, Rockford, $\mathrm{IL})$ according to the manufacturer's instructions. To detect $\beta_{1 \mathrm{c}}$ integrin, $200 \mu \mathrm{g}$ of detergent tissue extract was electrophoresed on a $7.5 \%$ SDS-polyacrylamide gel under reducing conditions, transferred to nitrocellulose (Schleicher \& Schuell, Keene, $\mathrm{NH}$ ), and immunostained as described, ${ }^{26}$ using either $5 \mu \mathrm{g} / \mathrm{ml}$ affinity-purified antibody to $\beta_{1 \mathrm{C}} ; 5 \mu \mathrm{g} / \mathrm{ml}$ nonimmune rabbit IgG; or 2.5 $\mu \mathrm{g} / \mathrm{ml} \mathrm{mAb} 13$, monoclonal antibody to $\beta_{1}$ integrin.

$\mathrm{BPH}-1$ cells were surface iodinated and proteins immunoprecipitated using rabbit antisera to $\beta_{1 \mathrm{C}}$ or to $\beta_{1 \mathrm{~A}}$ or 

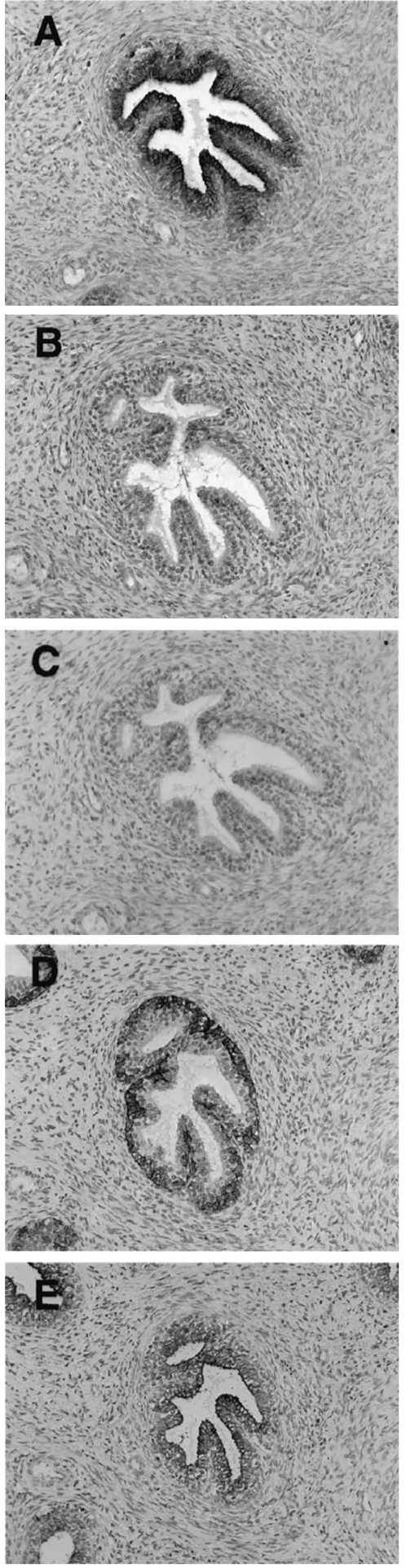

Figure 3. Expression of $\beta_{1 \mathrm{C}}$ in luminal epithelium of fetal prostate. The immunohistochemical analysis was performed on a 20-week-old fetus using $1.85 \mu \mathrm{g} / \mathrm{ml}$ affinity-purified antibody to $\beta_{1 \mathrm{C}}$ (A and C); $1.85 \mu \mathrm{g} / \mathrm{ml}$ nonimmune rabbit IgG (B); or $0.2 \mu \mathrm{g} / \mathrm{ml} 34 \beta \mathrm{E} 12$, monoclonal antibody to cytokeratins $1,5,10$, and 14 (D); or $5 \mu \mathrm{g} / \mathrm{ml} \mathrm{AE} 1 / \mathrm{AE} 3$, monoclonal antibody to type I and type II cytokeratins (E). The $\beta_{1 \mathrm{C}}$ immunostaining was specifically inhibited by antibody absorption on the $\beta_{1 \mathrm{C}} 785$ to 808 peptide $(30 \mu \mathrm{g} / \mathrm{ml})$ used as antigen $(C)$. Magnification, $\times 100$. Note that $\beta_{1 C}$ expression is undetectable in the basal layer of the fetal prostate gland $(\mathrm{A})$. using normal rabbit serum, as previously described. ${ }^{12}$ The immunocomplexes were separated on a $7.5 \%$ SDSpolyacrylamide gel under reducing conditions and visualized by autoradiography.

\section{Inducible Expression of CD4- $\beta_{1 C}$ and $C D 4-\beta_{1 A}$ Chimeric Constructs}

HindIII DNA fragment, encoding the cytoplasmic domain of $\beta_{1 \mathrm{C}}$ (nucleotides 2357 to 2613), ${ }^{25}$ was isolated from the pBJ1- $\beta_{1 \mathrm{C}}$ plasmid. The fragment was inserted into the HindllI site of the Ch2 chimera described by Lukashev et $\mathrm{al}^{22}$ which consists of the extracellular domain of murine CD4 joined to the transmembrane domain of the $\beta_{1}$ integrin. The resulting construct was designated $\mathrm{Ch} \beta_{1 \mathrm{C}}$. Correct assembly of the construct was verified by nucleotide sequencing. The Ch1 chimeric construct, designated here $\mathrm{Ch}_{1} \beta_{1 \mathrm{~A}}$, containing the extracellular domain of murine CD4 and the transmembrane and cytoplasmic domains of the $\beta_{1 \mathrm{~A}}$ integrin, has been described by Lukashev et al. ${ }^{22}$ Each chimeric construct is expressed under the control of the mouse metallothionein I promoter, which can be induced by addition of $\mathrm{ZnSO}_{4}$ to the growth medium. PC3 cells were electroporated using a Genepulser apparatus set at $250 \mathrm{~V}$ and $900 \mu \mathrm{F}$ using either 10 or $30 \mu \mathrm{g}$ of the $\mathrm{Ch} 1 \beta_{1 \mathrm{~A}}$ or the $\mathrm{Ch} \beta_{1 \mathrm{C}}$ chimera, respectively. Hygromycin-resistant cells were selected using growth medium containing $0.2 \mathrm{mg} / \mathrm{ml}$ hygromycin $\mathrm{B}$ (Boehringer Mannheim). Hygromycin-resistant colonies were pooled, and the resultant population was analyzed for cell surface expression of each chimeric construct by fluorescence-activated cell sorting using rat monoclonal antibody to mouse CD4. As negative control antibody, isotype-matched rat IgG was used. Stable transfectants were maintained in growth medium containing $0.2 \mathrm{mg} / \mathrm{ml}$ hygromycin B.

\section{Cell Proliferation Assay}

PC3 stable transfectants were starved for 24 hours in serum-free medium. Surface expression of chimeric constructs was induced by treating the cells with $75 \mu \mathrm{mol} / \mathrm{L}$ $\mathrm{ZnSO}_{4}$ (Sigma) in growth medium for 6 hours at $37^{\circ} \mathrm{C}$. Cells were then detached with $0.05 \%$ trypsin $/ 0.53 \mathrm{mmol} / \mathrm{L}$ ethylenediaminetetraacetic acid (Life Technologies), washed three times in serum-free medium, and analyzed by fluorescence-activated cell sorting using rat monoclonal antibody to mouse CD4 or isotype-matched rat IgG. Positive cells expressing comparable levels of the chimeric constructs were sorted using FACStar (Becton Dickinson). After sorting, the cell transfectants $\left(15 \times 10^{3}\right)$ were resuspended in serum-free medium and added to 96-well microtiter plates (ICN Biomedicals, Costa Mesa, CA) coated with $3 \mu \mathrm{g} / \mathrm{ml}$ fibronectin to ensure comparable attachment. After 1 hour and 30 minutes at $37^{\circ} \mathrm{C}$, cells were washed twice, incubated either in the absence or in the presence of $10 \%$ FCS for 18 hours at $37^{\circ} \mathrm{C}$, and pulsed with $1 \mu \mathrm{Ci}\left[{ }^{3} \mathrm{H}\right]$ thymidine/well $(5.0 \mathrm{Ci} / \mathrm{mmol}$; Amersham Life Sciences, Arlington Heights, IL) during the last 

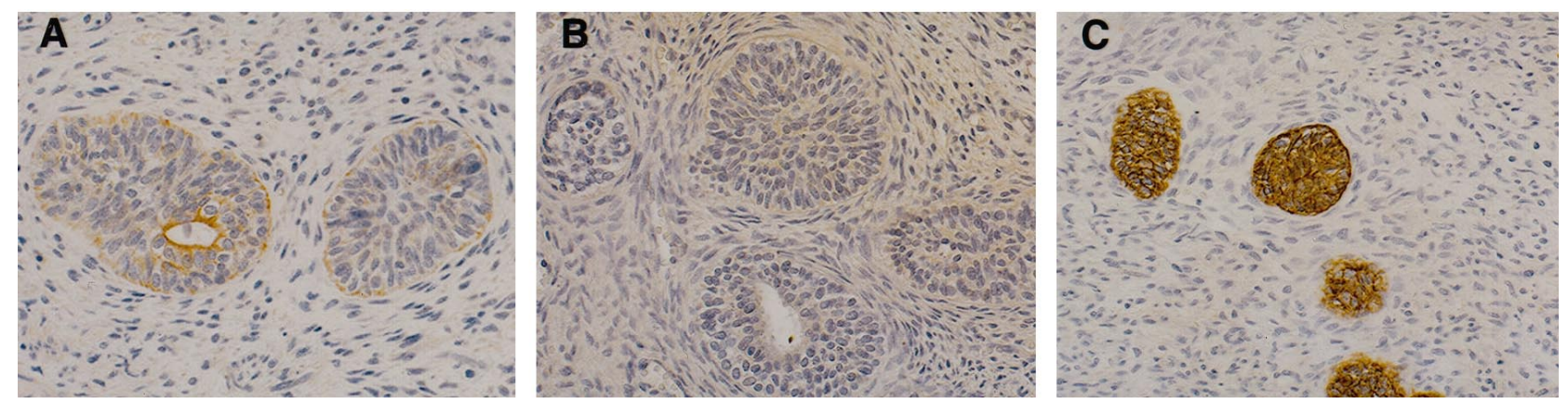

Figure 4. Expression of $\beta_{1 \mathrm{C}}$ in prostate budding glands. The immunohistochemical analysis was performed on a 20 -week-old fetus using $1.85 \mu \mathrm{g} / \mathrm{ml}$ affinity-purified antibody to $\beta_{1 \mathrm{C}}(\mathrm{A}) ; 1.85 \mu \mathrm{g} / \mathrm{ml}$ of nonimmune rabbit IgG (B); or $1.25 \mu \mathrm{g} / \mathrm{ml}$ CAM 5.2 , monoclonal antibody to cytokeratins 8 and 18 (C). Magnification, $\times 200$. The expression of $\beta_{1 \mathrm{C}}$ coincides with a differentiated phenotype of the prostate gland: note that $\beta_{1 \mathrm{C}}$ is detectable only when a lumen is well defined in the gland.

3 hours of the 18-hour culture. Thymidine incorporation was evaluated as described. ${ }^{12}$ In each experiment, duplicate or triplicate observations were performed, and the values are reported as mean \pm standard error (SE). In parallel, in each experiment, the number of attached cells was evaluated after fixing and staining the cells with $0.5 \%$ crystal violet (Sigma), as described. ${ }^{29}$ The results were evaluated using a 630-nm wavelength filter in a Titertek Multiskan Bichromatic enzyme-linked immunosorbent assay reader (ICN). Group differences were compared using one-way analysis of variance followed by Bonferroni post hoc contrast.
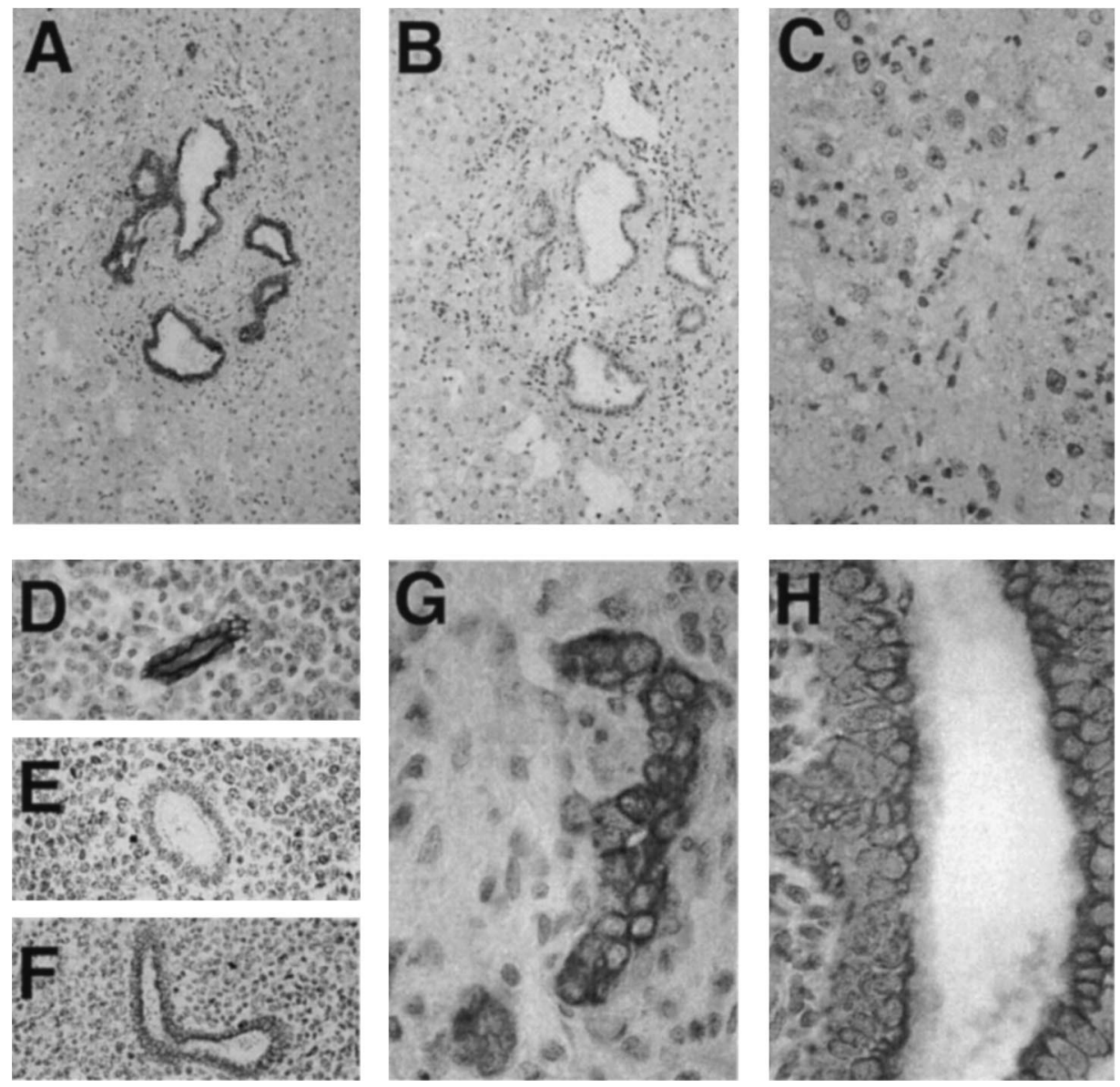

Figure 5. The $\beta_{1 \mathrm{C}}$ integrin is expressed in adult and fetal liver bile ducts but not in hepatocytes. Immunoperoxidase staining of $\beta_{1 \mathrm{C}}$ was performed on adult (A through $F$ ) and 19-week-old fetal $(G$ and $H)$ liver using $5 \mu \mathrm{g} / \mathrm{ml}$ affinity-purified antibody to $\beta_{1 \mathrm{C}}(\mathrm{A}, \mathrm{C}$ through $\mathrm{E}, \mathrm{G}$, and $\mathrm{H})$ or $5 \mu \mathrm{g} / \mathrm{ml}$ nonimmune rabbit IgG (B). The $\beta_{1 \mathrm{C}}$ immunostaining (D) was specifically inhibited by antibody absorption on the $\beta_{1 \mathrm{C}} 785$ to 808 peptide $(10 \mu \mathrm{g} / \mathrm{ml})$ used as antigen (E), not on an irrelevant peptide (F). Magnification, $\times 100\left(A\right.$ and B); $\times 200$ (C through F), and $\times 400(G$ and $H)$. Note strong $\beta_{1 C}$ immunoreactivity in the bile ducts $(A, D, F$, $\mathrm{G}$, and $\mathrm{H})$ and not in hepatocytes (C and $\mathrm{G})$. 

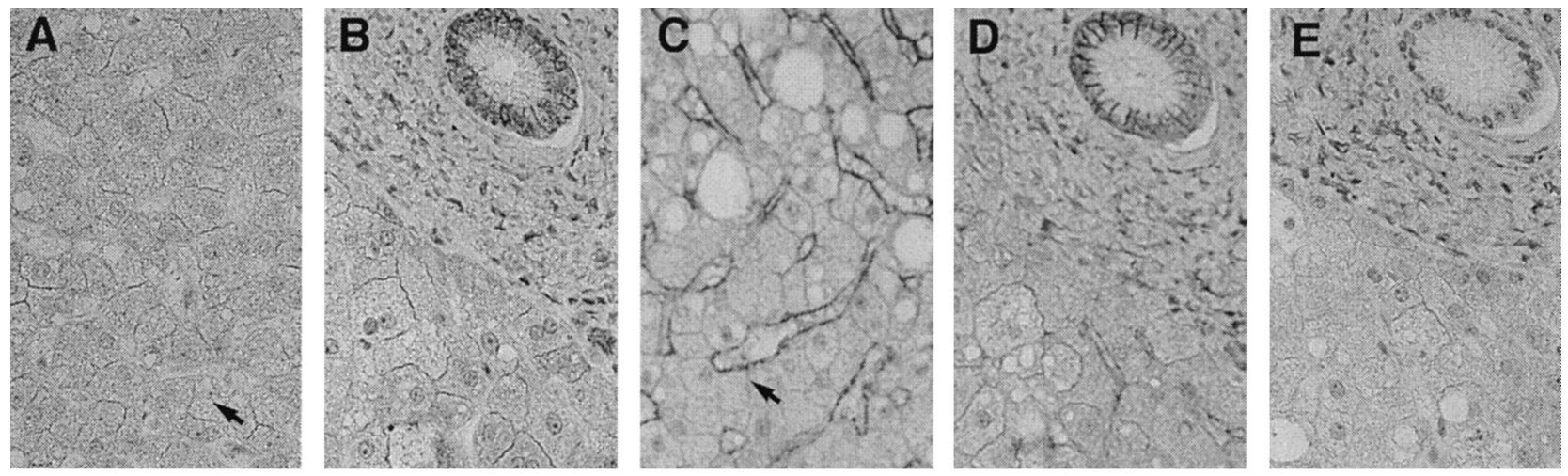

\section{$\beta_{1 \mathrm{C}}$}

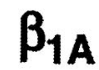

Control

Figure 6. Differential expression of $\beta_{1 \mathrm{C}}$ and $\beta_{1 \mathrm{~A}}$ in adult liver. Immunoperoxidase staining of $\beta_{1 \mathrm{C}}$ and $\beta_{1 \mathrm{~A}}$ in liver with mild parenchyma alterations (steatohepatitis) was performed using $5 \mu \mathrm{g} / \mathrm{ml}$ affinity-purified antibodies to $\beta_{1 \mathrm{C}}\left(\mathrm{A}\right.$ and $\mathrm{B}$ ) or to $\beta_{1 \mathrm{~A}}(\mathrm{C}$ and $\mathrm{D})$ ). Nonimmune rabbit IgG (5 $\left.\mu \mathrm{g} / \mathrm{ml}\right)$ was used as a negative control (E). Magnification, $\times 200$. Note, $\beta_{1 \mathrm{C}}$ is selectively expressed in biliary epithelium (B), whereas $\beta_{1 \mathrm{~A}}$ is found in bile ducts (D), as well as in sinusoids (C). Arrows (A and $\mathrm{C}$ ) point to sinusoids.

\section{Results}

\section{$\beta_{1 \mathrm{c}}$ Expression in Epithelial Cells in Adult and Fetal Tissues}

Immunohistochemical analysis of adult and fetal human tissue specimens was performed using an affinity-purified antibody to $\beta_{1 \mathrm{c}} ; \beta_{1 \mathrm{C}}$ was detected in a subset of epithelial cells. Specifically, simple or pseudostratified epithelia in prostate, liver, gallbladder, lung, and kidney were positive for $\beta_{1 \mathrm{C}}$ (see Figures 1 through 6 and 8 , and data not shown) in all the analyzed cases, whereas stratified squamous epithelium of the epidermis was negative (Figure 1E). In the prostate, $\beta_{1 \mathrm{C}}$ was preferentially expressed in the luminal glandular epithelium (Figure 1A). In contrast, the basal epithelium, composed of proliferating cells ${ }^{30}$ identified by an antibody to basal cell-specific cytokeratins 1, 5, 10, and 14 (Figure 1D), did not reveal detectable levels of $\beta_{1 \mathrm{C}}$ (Figure 1A). Similarly, $\beta_{1 \mathrm{C}}$ immunoreactivity was undetectable in stromal and endothelial cells in all the analyzed tissues (see Figures 1 through 6). The specificity of the immunoreactivity of the antibody to $\beta_{1 \mathrm{C}}$ (Figure 2A) was confirmed by 1 ) inhibition by the $\beta_{1 \mathrm{C}}$ peptide, 785 to 808 , used as the antigen (Figure 2B), 2) immunoblotting of detergent lysate of prostate tissue (Figure 2E), and 3) immunoprecipitation of surface-iodinated BPH-1 luminal epithelial cells (Figure 2F). The immunoblotting and immunoprecipitation both revealed bands with an electrophoretic mobility similar to that of $\beta_{1 \mathrm{~A}}$ (Figure 2, E and F). ${ }^{12}$

Immunohistochemical analysis performed on secondtrimester fetal tissues showed that, as in adult tissue, $\beta_{1 \mathrm{C}}$ was confined to glandular epithelium in completely differentiated glands with a defined lumen (Figures $3 \mathrm{~A}$ and $4 \mathrm{~A}$ and not shown), whereas it was absent in budding glands (Figure 4A). Cytokeratin 8 and 18 staining was used for the identification of prostate glands ${ }^{31}$ that had not differentiated completely and lacked a lumen (Figure 4C). The basal epithelium, identified using an antibody to basal cell-specific cytokeratins 1, 5, 10, and 14 (Figure $3 \mathrm{D})$, did not contain detectable $\beta_{1 \mathrm{C}}$ (Figure 3A). The specificity of $\beta_{1 \mathrm{C}}$ immunoreactivity (Figure 3A) was confirmed by inhibitions with the $\beta_{1 \mathrm{c}}$ peptide used as the antigen (Figure $3 C$ ). These staining results suggest that $\beta_{1 \mathrm{C}}$ is a marker of prostate epithelial cell differentiation.

In the adult liver, $\beta_{1 \mathrm{c}}$ immunoreactivity was restricted to biliary epithelium (Figure 5, A, D, and F), which stained at the apical, basal, and lateral cell surfaces; no $\beta_{1 \mathrm{C}}$ was found in hepatocytes (Figure $5 \mathrm{C}$ ). A similar staining pattern showing expression in bile ducts, but not in hepatocytes, was observed in 16, 17, and 19 week-gestation fetal livers (Figure 5, $G$ and $H$, and not shown). The specificity of the staining was confirmed by inhibition with the $\beta_{1 \mathrm{C}}$ peptide (Figure 5E). The control of $\beta_{1 \mathrm{C}}$ expression appears to be independent of $\beta_{1 \mathrm{~A}}$, as the two variants are differentially regulated in a cell type-specific manner. In contrast to $\beta_{1 \mathrm{C}}$, which has a distribution restricted to biliary epithelium (Figure $6, A$ and B), the $\beta_{1 \mathrm{~A}}$ variant was found in bile duct epithelium (Figure 6D); hepatic vasculature (Figure 6C and not shown); and, weakly, in hepatocytes, as shown previously. ${ }^{32}$

\section{$\beta_{1 C}$ Inhibits Epithelial Cell Proliferation}

Because $\beta_{1 \mathrm{C}}$ has a powerful growth-inhibitory activity in fibroblasts $^{12,13}$ and because, as shown above, it is predominantly found in nonproliferative epithelium, we explored the possibility that $\beta_{1 \mathrm{c}}$ would have a causal role in inhibiting epithelial cell proliferation. Chimeric constructs containing either $\beta_{1 \mathrm{C}}\left(\mathrm{Ch} \beta_{1 \mathrm{C}}\right.$; Figure $7, \mathrm{~A}$ and $\left.\mathrm{B}\right)$ or $\beta_{1 \mathrm{~A}}$ (Ch1 $\beta_{1 \mathrm{~A}}$; Figure $7, \mathrm{C}$ and D) cytoplasmic tails under the control of an inducible promoter were stably expressed in PC3 prostate cancer cells. Serum-starved stable transfectants were incubated with $\mathrm{ZnSO}_{4}$ (Figure 7, A and C) to induce surface expression of the chimeric proteins and sorted by fluorescence-activated cell sorting to isolate positive cells expressing comparable levels of $\mathrm{Ch} \beta_{1 \mathrm{c}}$ or 

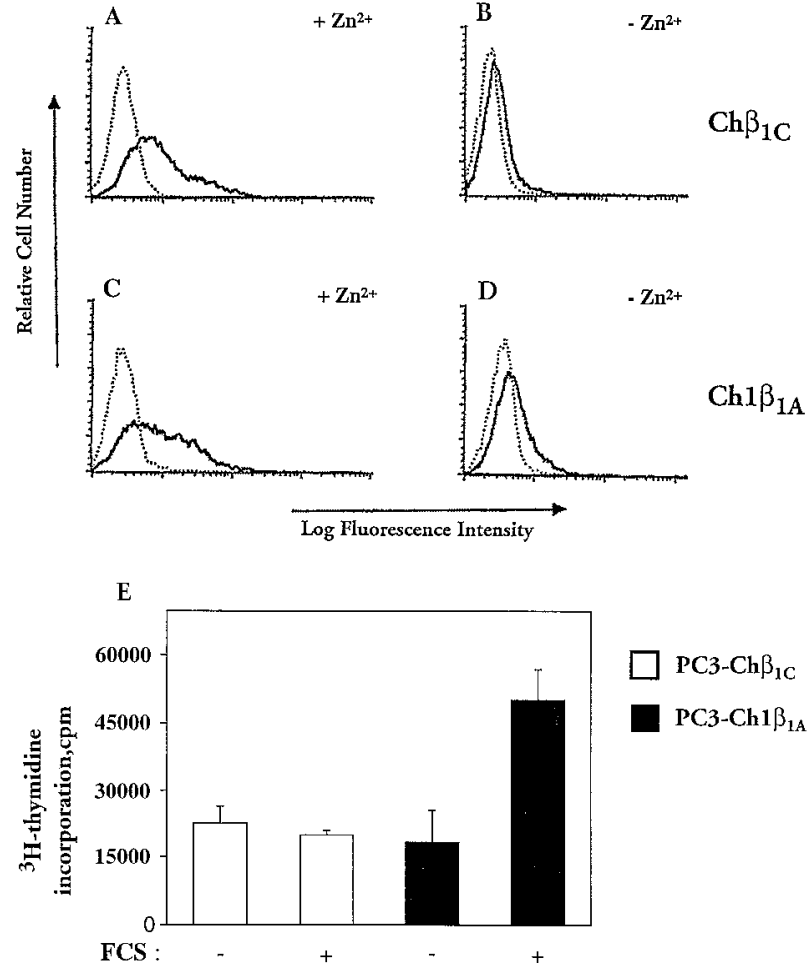

Figure 7. Inhibition of prostate cell growth in response to $\beta_{1 \mathrm{C}}$ expression. PC3 cells were stably transfected using chimeric constructs containing the cytoplasmic domain of either $\beta_{1 \mathrm{C}}\left(\mathrm{Ch} \beta_{1 \mathrm{C}}, \mathrm{A}\right.$ and $\left.\mathrm{B}\right)$ of $\beta_{1 \mathrm{~A}}\left(\mathrm{Ch} 1 \beta_{1 \mathrm{~A}}, \mathrm{C}\right.$ and D). Serum-starved stable transfectants were incubated either in the absence (C and D) or in the presence of $75 \mu \mathrm{mol} / \mathrm{L} \mathrm{ZnSO}_{4}(A$ and $C$ ) for 6 hours at $37^{\circ} \mathrm{C}$ in growth medium to induce surface expression of the chimeric proteins (A and C). Stable cell transfectants were then stained with fluorescein isothiocyanate-conjugated rat monoclonal antibody to mouse CD4 (solid line) or isotype-matched fluorescein isothiocyanate-conjugated rat IgG (dotted line) and sorted by fluorescence-activated cell sorting to isolate positive cells expressing comparable levels of $\mathrm{Ch} \beta_{1 \mathrm{C}}$ or $\mathrm{Ch} 1 \beta_{1 \mathrm{~A}}$. The $\mathrm{Ch} \beta_{1 \mathrm{C}}$ and the $\operatorname{Ch} 1 \beta_{1 \mathrm{~A}}$ sorted cells were compared in proliferation assays $(\mathrm{E})$ on 96-well plates coated with $3 \mu \mathrm{g} / \mathrm{ml}$ fibronectin. Attached cells were incubated for 15 hours at $37^{\circ} \mathrm{C}$ either in the absence or in the presence of $10 \%$ FCS and then for an additional 3 hours at $37^{\circ} \mathrm{C}$ with $1 \mu \mathrm{Ci} /$ well $\left[{ }^{3} \mathrm{H}\right]$ thymidine to measure their proliferative response to FCS. Results are mean \pm SE values of duplicate determinations. Group differences were compared using one-way analysis of variance followed by Bonferroni post hoc contrast. The differences in proliferation between $\mathrm{Ch} \beta_{1 \mathrm{C}}$ and $\mathrm{Ch} 1 \beta_{1 \mathrm{~A}}$ transfectants in the presence of $10 \%$ FCS and between nonstimulated and 10\% FCS-stimulated Ch $1 \beta_{1 \mathrm{~A}}$ transfectants are statistically significant $(P<0.05)$. A representative experiment of three is shown.

Ch1 $\beta_{1 \mathrm{~A}}$. The sorted cells were compared in proliferation assays on fibronectin (Figure 7E). Under the experimental conditions used, adhesion to fibronectin was not affected by the expression of either $\operatorname{Ch} \beta_{1 \mathrm{C}}$ or $\mathrm{Ch} 1 \beta_{1 \mathrm{~A}}$ (not shown). However, the expression of $\beta_{1 \mathrm{C}}$ completely inhibited thymidine incorporation in response to serum in the cells, whereas $\beta_{1 \mathrm{~A}}$ had no effect.

The in vitro data showing strong inhibition of prostate epithelial cell proliferation by $\beta_{1 \mathrm{c}}$ were further supported by immunohistochemical analysis of regenerative areas of hyperplastic prostate tissues. Luminal expression of $\beta_{1 \mathrm{C}}$ (Figure 8A), which was observed in normal and hyperplastic prostatic glandular epithelia of all the analyzed cases, was selectively downregulated in regenerative areas displaying hyperchromatic nuclei and cellular crowding (Figure $8, \mathrm{C}$ and D). $\beta_{1 \mathrm{~A}}$ was always detected in both the basal and luminal layers (Figure 8B, and not shown).
These results suggest a unique role for $\beta_{1 \mathrm{C}}$ in controlling epithelial cell proliferation under normal and pathological conditions.

\section{Discussion}

The results described here show that the $\beta_{1 \mathrm{C}}$ integrin, an alternatively spliced variant of the $\beta_{1}$ subunit, ${ }^{25}$ is expressed in vivo in a cell type-specific manner, predominantly in nonproliferating differentiated epithelial cells, and that is an early marker of differentiation of prostate epithelium. We also show that $\beta_{1 \mathrm{C}}$ inhibits in vitro growth of malignant epithelial cells from the prostate.

Our in vivo study shows a selective expression of $\beta_{1 \mathrm{C}}$ in a subset of epithelial cells that does overlap with the expression of $\beta_{1 \mathrm{~A}}$. This analysis of $\beta_{1 \mathrm{C}}$ distribution was made possible by the availability of highly specific antibodies to the $\beta_{1 \mathrm{c}}$ cytoplasmic domain and emphasizes the importance of using antibodies specific to the different variants when analyzing $\beta_{1}$ distribution. The $\beta_{1 \mathrm{C}}$ distribution is unique among the $\beta_{1}$ variants. The $\beta_{1 \mathrm{~B}}$ isoform has been found to be restricted to skin and liver tissues, ${ }^{33}$ whereas the $\beta_{1 \mathrm{D}}$ subunit is expressed in striated muscles, where it replaces $\beta_{1 \mathrm{~A}}^{19,34}$ in a developmentally regulated manner. ${ }^{35}$

Functional differences have been described for the $\beta_{1}$ variants. $\beta_{1 \mathrm{D}}$ is functionally similar to $\beta_{1 \mathrm{~A}}$, in that both are localized at focal contacts and can stimulate focal adhesion kinase activation, ${ }^{19,34}$ whereas $\beta_{1 \mathrm{~B}}$ inhibits it. ${ }^{15}$ This suggests that modulation of splicing patterns of $\beta_{1}$ mRNA may provide an accessory mechanism to regulate signaling pathways initiated by integrins. A recent study shows that the ability of $\beta_{1 \mathrm{C}}$ to inhibit cell proliferation is shared by $\beta_{1 \mathrm{D}}{ }^{36}$; however, the downstream signaling pathways by these variants are unknown and may be different.

The mechanisms that regulate epithelial cell proliferation and differentiation in developing embryonal and fetal tissue are largely unknown. In general terms during organogenesis, a proliferative phase is followed by one in which the cells progressively differentiate and acquire the phenotype required for their highly specialized functions. ${ }^{37}$ The results of our study indicate that $\beta_{1 \mathrm{C}}$ is expressed at the transition between these phases and suggest that its expression might be an important mechanism by which cellular proliferation is inhibited in differentiating fetal epithelia in specific organs.

Altered expression of integrins in epithelial cells has been shown to generate pathological phenotypes. ${ }^{32} \mathrm{Ab}$ normal expression of $\beta_{1}$ in the suprabasal epidermal layers of the skin causes epidermal hyperproliferation, as shown in studies performed using transgenic mice, thus confirming that incorrect integrin distribution can be a trigger for increased in vivo growth rate. ${ }^{38,39}$ In normal skin, $\beta_{1}$ integrins are found only in the basal layer of the epidermis, whereas during wound healing and psoriasis, which are associated with hyperproliferation, they also appear in the suprabasal layers of the skin. ${ }^{40}$ Integrin expression affects the growth of tumor cells in vitro and tumor growth and metastasis in vivo. ${ }^{41-50}$ On the basis of 
1086 Fornaro et al

AJP October 1998, Vol. 153, No. 4
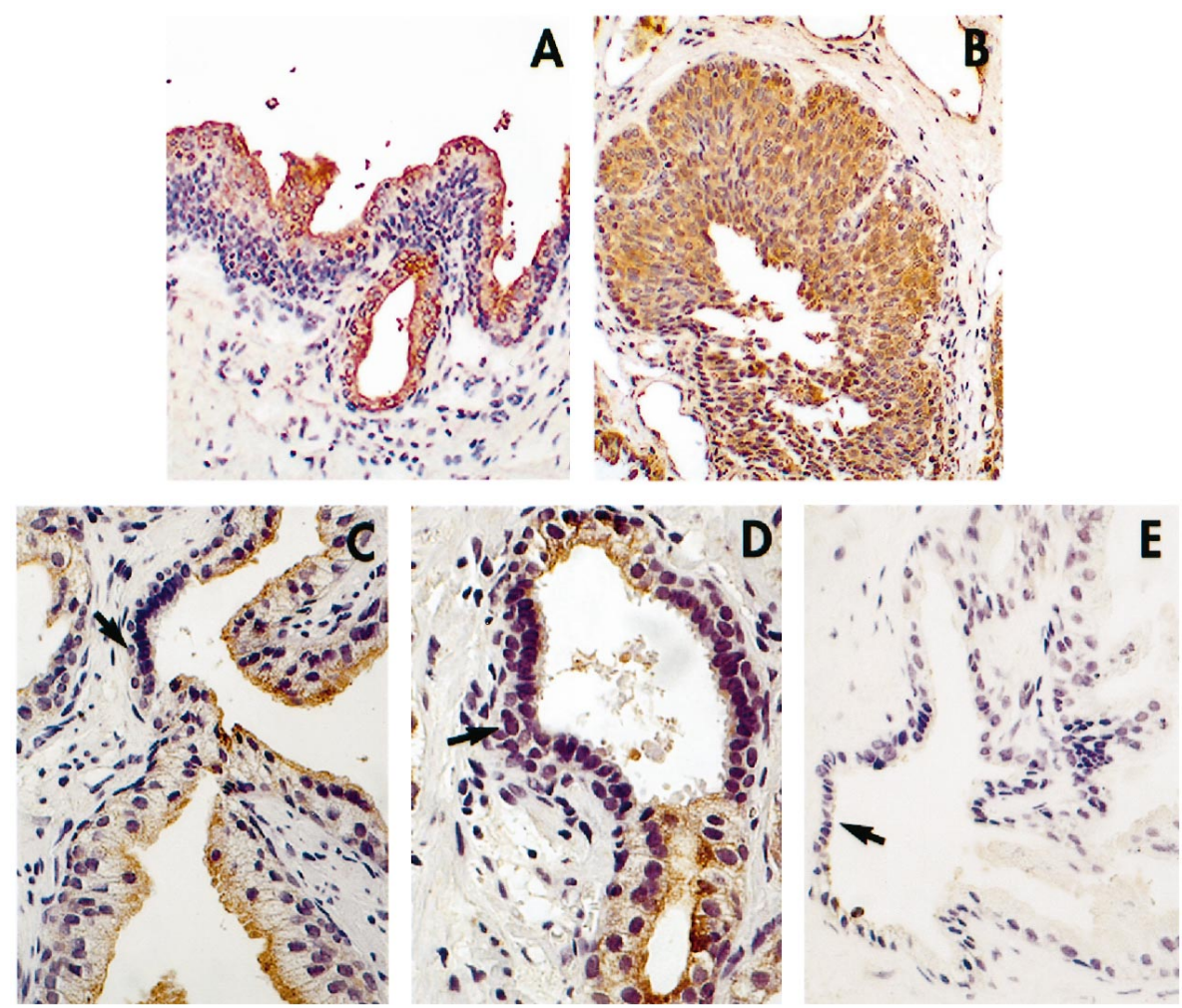

Figure 8. $\beta_{1 \mathrm{C}}$ is down regulated in regenerative areas of prostate glands. Prostate tissue sections from a hyperplastic specimen were analyzed by immunohistochemistry using $3.75 \mu \mathrm{g} / \mathrm{ml}$ affinity-purified antibody to $\beta_{1 \mathrm{C}}$ (A, C, and D); $2 \mu \mathrm{g} / \mathrm{ml}$ affinity-purified antibody to $\beta_{1 \mathrm{~A}}$ (B); of $3.75 \mu \mathrm{g} / \mathrm{ml}$ nonimmune rabbit IgG (E). Magnification, $\times 200$ (A and B) and $\times 400$ (C through E) Regenerative areas displaying hyperchromatic nuclei and cellular crowding. (arrows, $C$ and D), downregulate $\beta_{1 \mathrm{C}}$, suggesting a selective loss of expression of $\beta_{1 \mathrm{C}}$ in proliferative areas. The results also show that $\beta_{1 \mathrm{C}}$ and $\beta_{1 \mathrm{~A}}$ are differentially expressed in prostate epithelial cells; specifically, basal cells fail to express $\beta_{1 \mathrm{C}}$ (A) but strongly express $\beta_{1 \mathrm{~A}}$ (B).

the different effects of $\beta_{1 \mathrm{C}}$ and $\beta_{1 \mathrm{~A}}$ on cell proliferation, we would predict that replacement of the $\beta_{1 \mathrm{C}}$ with $\beta_{1 \mathrm{~A}}$ could also lead to abnormal proliferation in epithelium.

The expression of $\beta_{1 C}$ completely inhibited thymidine incorporation of prostate cancer epithelial cells in response to serum. Consistent with these in vitro results, $\beta_{1 C}$ appeared to be downregulated in prostate glands that exhibit regenerative features in benign hyperplastic epithelium. These observations, and previous findings showing that $\beta_{1 \mathrm{C}}$ is downregulated in prostate cancer, ${ }^{26}$ suggest that the loss of $\beta_{1 \mathrm{C}}$ expression may contribute malignant progression in prostate cells.

\section{Acknowledgments}

We thank Drs. Simon W. Hayward, Matvey E. Lukashev, Robert M. Pytela, and Kenneth M. Yamada for reagents; Rocco Carbone for support in performing flow cytometric analysis; Mary Helie and Linda Gutierrez de Castejon in the Department of Pathology for technical advice; and Nancy Bennett for assisting with the preparation of the manuscript.

\section{References}

1. Brakebusch C, Hirsch E, Potocnik A, Fassler R: Genetic analysis of $\beta_{1}$ integrin function: confirmed, new and revised role for a crucial family of cell adhesion molecules. J Cell Sci 1997, 110:2895-2904
2. Damsky CH, Werb Z: Signal transduction by integrin receptors for extracellular matrix: cooperative processing of extracellular information. Curr Opin Cell Biol 1992, 4:772-781

3. Ruoslahti E, Reed JC: Anchorage dependence, integrins and apoptosis. Cell 1994, 77:477-478

4. Varner JA, Cheresh DA: Integrins and cancer. Curr Opin Cell Biol 1996, 8:724-730

5. Haas TA, Plow EF: Integrin-ligand interactions: a year in review. Curr Opin Cell Biol 1994, 6:656-662

6. Hynes RO: Integrins: versatility, modulation and signaling in cell adhesion. Cell 1992, 69:11-25

7. Schwartz MA, Schaller MD, Ginsberg MH: Integrins: emerging paradigms of signal transduction. Annu Rev Cell Dev Biol 1995, 11:549599

8. Fornaro M, Languino LR: Alternatively spliced variants: a new view of the integrin cytoplasmic domain. Matrix Biol 1997, 16:185-193

9. Williams MJ, Hughes PE, O'Toole TE, Ginsberg MH: The inner world of cell adhesion: integrin cytoplasmic domains. Trends Cell Biol 1994 4:109-112

10. Hemler ME, Weitzman JB, Pasqualini R, Kawaguchi S, Kassner PD, Berdichevsky FB: Structure, biochemical properties, and biological functions of integrin cytoplasmic domains. Integrins: The Biological Problems. Edited by Y Takada. Ann Arbor, CRC Press, 1995, pp 1-35

11. Marcantonio EE, Hynes RO: Antibodies to the conserved cytoplasmic domain of the integrin $\beta_{1}$ subunit react with proteins in vertebrates, invertebrates and fungi. J Cell Biol 1988, 106:1765-1772

12. Fornaro $M$, Zheng $D Q$, Languino LR: The novel structural motif Gln ${ }^{795}$ $\mathrm{Gl} \mathrm{n}^{802}$ in the integrin $\beta_{1 \mathrm{C}}$ cytoplasmic domain regulates cell proliferation. J Biol Chem 1995, 270:24666-24669

13. Meredith J Jr, Takada Y, Fornaro M, Languino LR, Schwartz MA: Inhibition of cell cycle progression by the alternatively spliced integrin $\beta_{1 \mathrm{C}}$. Science 1995, 269:1570-1572

14. Baudoin C, Goumans M-J, Mummery C, Sonnenberg A: Knockout and knockin of the $\beta 1$ exon $\mathrm{D}$ define distinct roles for integrin splice 
variants in heart function and embryonic development. Genes Dev 1998, 12:1202-1216

15. Balzac F, Retta SF, Albini A, Melchiorri A, Koteliansky VE, Geuna M, Silengo L, Tarone G: Expression of $\beta_{1 \mathrm{~B}}$ integrin isoform in $\mathrm{CHO}$ cells results in a dominant negative effect on cell adhesion and motility. J Cell Biol 1994, 127:557-565

16. LaFlamme SE, Thomas LA, Yamada SS, Yamada KM: Single subunit chimeric integrins as mimics and inhibitors of endogenous integrin functions in receptor localization, cell spreading and migration, and matrix assembly. J Cell Biol 1994, 126:1287-1298

17. Marcantonio EE, Guan J-L, Trevithick JE, Hynes RO: Mapping of the functional determinants of the integrin $\beta_{1}$ cytoplasmic domain by site-directed mutagenesis. Cell Regul 1990, 1:597-604

18. Reszka AA, Hayashi $Y$, Horwitz AF: Identification of amino acid sequences in the integrin $\beta_{1}$ cytoplasmic domain implicated in cytoskeleton association. J Cell Biol 1992, 117:1321-1330

19. Belkin AM, Zhidkova NI, Balzac F, Altruda F, Tomatis D, Maier A, Tarone G, Koteliansky VE, Burridge K: $\beta_{1 \mathrm{D}}$ integrin displaces $\beta_{1 \mathrm{~A}}$ isoform in striated muscles: localization at junctional structures and signaling potential in non-muscle cells. J Cell Biol 1996, 132:211-226

20. Wei J, Shaw LM, Mercurio AM: Regulation of mitogen-activated protein kinase activation by the cytoplasmic domain of the $\alpha 6$ integrin subunit. J Biol Chem 1998, 273:5903-5907

21. Akiyama SK, Yamada SS, Yamada KM, LaFlamme SE: Transmembrane signal transduction by integrin cytoplasmic domains expressed in single-subunit chimeras. J Biol Chem 1994, 269:1596115964

22. Lukashev ME, Sheppard D, Pytela R: Disruption of integrin function, and induction of tyrosine phosphorylation, by the autonomously expressed $\beta_{1}$ integrin cytoplasmic domain. J Biol Chem 1994, 269: 18311-18314

23. Schaller MD, Parsons JT: Focal adhesion kinase and associated proteins. Curr Opin Cell Biol 1994, 6:705-710

24. Zhang $\mathrm{H}$, Tan SM, Lu J: cDNA cloning reveals two mouse $\beta 5$ integrin transcripts distinct in cytoplasmic domains as a result of alternative splicing. Biochem J 1998, 331:631-637

25. Languino LR, Ruoslahti $E$ : An alternative form of the integrin $\beta_{1}$ subunit with a variant cytoplasmic domain. J Biol Chem 1992, 267 : $7116-7120$

26. Fornaro M, Tallini G, Bofetiado CJM, Bosari S, Languino LR: Downregulation of $\beta_{1 \mathrm{C}}$ integrin, an inhibitor of cell proliferation, in prostate carcinoma. Am J Pathol 1996, 149:765-773

27. Hayward SW, Cunha GR, Bartek J, Deshpande N, Narayan P: Establishment and characterization of an immortalized but not transformed human prostate epithelial cell line: BPH-1. In Vitro Cell Dev Biol Anim 1995, 31:14-24

28. Languino LR, Duperray A, Joganic KJ, Fornaro M, Thornton GB, Altieri DC: Regulation of leukocyte-endothelium interaction and leukocyte transendothelial migration by ICAM1-fibrinogen recognition. Proc Natl Acad Sci USA 1995, 92:1505-1509

29. Languino LR, Gehlsen KR, Wayner E, Carter WG, Engvall E, Ruoslahti E: Endothelial cells use $\alpha_{2} \beta_{1}$ integrin as a laminin receptor. J Cell Biol 1989, 109:2455-2462

30. Mao P, Angrist A: The fine structure of the basal cells of human prostate. Lab Invest 1966, 15:1768-1782

31. Xue Y, Smedts F, Debruyne FM, de la Rosette JJ, Schalken JA: Identification of intermediate cell types by keratin expression in the developing human prostate. Prostate 1998, 34:292-301

32. Scoazec JV: Expression of cell-matrix adhesion molecules in the liver and their modulation during fibrosis. J Hepatol 1995, 22:20-27
33. Balzac F, Belkin AM, Koteliansky VE, Balabanov YV, Altruda F, Silengo L, Tarone G: Expression and functional analysis of a cytoplasmic domain variant of the $\beta_{1}$ integrin subunit. J Cell Biol 1993, 121:171-178

34. Belkin AM, Retta SF, Pletjushkina OY, Balzac F, Silengo L, Fassler R, Koteliansky VE, Burridge K, Tarone G: Muscle $\beta 1 \mathrm{D}$ integrin reinforces the cytoskeleton-matrix link: modulation of integrin adhesive function by alternative splicing. J Cell Biol 1997, 139:1583-1595

35. Brancaccio M, Cabodi S, Belkin AM, Collo G, Koteliansky VE, Tomatis $D$, Altruda F, Silengo L, Tarone G: Differential onset of expression of $\alpha_{7}$ and $\beta_{1 \mathrm{D}}$ integrin during mouse heart and skeletal muscle development. Cell Adhes Commun 1998, 5:193-205

36. Belkin AM, Retta SF: $\beta_{1 \mathrm{D}}$ integrin inhibits cell cycle progression in normal myoblasts and fibroblasts. J Biol Chem 1998, 273:1523415240

37. Moore KL, Persud TVN: The Developing Human: Clinically Oriented Embryology. Edited by KL Moore, TVN Persud. Philadelphia, WB Saunders Co, 1998

38. Carroll JM, Romero RM, Watt FM: Suprabasal integrin expression in epidermis of transgenic mice results in developmental defects and a phenotype resembling psoriasis. Cell 1995, 83:957-968

39. Frenette PS, Wagner DD: Molecular medicine: adhesion molecules, part I. N Engl J Med 1996, 334:1526-1529

40. Hertle MD, Kubler M-D, Leigh IM, Watt FM: Aberrant integrin expression during epidermal wound healing and in psoriatic epidermis. J Clin Invest 1992, 89:1892-1901

41. Albelda SM: Biology of disease: role of integrins and other cell adhesion molecules in tumor progression and metastasis. Lab Invest 1993, 68:4-17

42. Ruoslahti E: Integrins as signaling molecules and targets for tumor therapy. Kidney Int 1997, 51:1413-1417

43. Bonkhoff $H$, Stein $U$, Remberger K: Differential expression of $\alpha 6$ and $\alpha 2$ very late antigen integrins in the normal, hyperplastic, and neoplastic prostate: simultaneous demonstration of cell surface receptors and their extracellular ligands. Hum Pathol 1993, 24:243-248

44. Knox JD, Cress AE, Clark V, Manriquez L, Affinito KS, Dalkin BL, Nagle RB: Differential expression of extracellular matrix molecules and the $\alpha_{6}$-integrins in the normal and neoplastic prostate. Am J Pathol 1994, 145:167-174

45. Nagle RB, Hao J, Knox JD, Dalkin BL, Clark V, Cress AE: Expression of hemidesomosomal and extracellular matrix proteins by normal and malignant human prostate tissue. Am J Pathol 1995, 146:1498-1507

46. Stroeken PJ, van Rijthoven E, van der Valk MA, Roos E: Targeted disruption of the $\beta_{1}$ integrin gene in a lymphoma cell line greatly reduces metastatic capacity. Cancer Res 1998, 58:1569-1577

47. Felding-Habermann B, Cheresh DA: Vitronectin and its receptors. Curr Opin Cell Biol 1993, 5:864-868

48. Witkowski M, Rabinovitz I, Nagle RB, Affinito KD, Cress AE: Characterization of integrin subunits, cellular adhesion and tumorigenicity of four human prostate cell lines. Cancer Res Clin Oncol 1993, 119:637644

49. Wewer UM, Shaw LM, Albrechtsen R, Mercurio AM: The integrin $\alpha_{6} \beta_{1}$ promotes the survival of metastatic human breast carcinoma cells in mice. Am J Pathol 1997, 151:1191-1197

50. Chao C, Lotz MM, Clarke AC, Mercurio AM: A function for the integrin $\alpha_{6} \beta_{4}$ in the invasive properties of colorectal carcinoma cells. Cancer Res 1996, 56:4811-4819 